\title{
NUMERICAL MODELLING OF THERMAL REGIME OF RAILWAY TRACK - STRUCTURE WITH THERMAL INSULATION (STYRODUR)
}

\author{
Libor IŽVOLT ${ }^{1}$, Peter DOBEŠ ${ }^{1}$, Michaela HOLEŠOVÁ $^{2}$, Deividas NAVIKAS ${ }^{3,4^{*}}$ \\ ${ }^{1}$ Department of Railway Engineering and Track Management, Univesity of Žilina, Žilina, Slovakia \\ ${ }^{2}$ Department of Structural Mechanics and Applied Mathematics, Univesity of Žilina, Žilina, Slovakia \\ ${ }^{3}$ Department of Mobile Machinery and Railway Transport, Vilnius Gediminas Technical University, Vilnius, Lithuania \\ ${ }^{4}$ Department of Automobiles Transport Engineering, Vilnius Technology and Design College, Vilnius, Lithuania
}

Received 13 July 2020; accepted 23 March 2021

\begin{abstract}
This paper presents the results of numerical modelling of the influence of various factors (geometrical layout of the structural layers of the railway track, climatic factors and ballast fouling) on the freezing of railway track structure with a built-in thermal insulation layer of extruded polystyrene (Styrodur). At the same time, the suitability and expediency of incorporating the thermal insulation layer at the sub-ballast upper surface level (i.e. below the rail ballast construction layer), or at the level of subgrade surface are discussed. Numerical modelling results in the main factors that should be taken into account in the dimensioning of the sub-ballast layers with a built-in thermal insulation layer. Based on the data on the depth of freezing of the railway track structure obtained from numerical modelling, a design nomogram for dimensioning was created and subsequently the influence of the changes of climatic characteristics on the freezing of the railway track structure was then mathematically expressed.
\end{abstract}

Keywords: railway track, non-traffic railway track loading, freezing of the railway track structure, sub-ballast layer dimensioning, thermal insulation layer, extruded polystyrene, thickness of protective layer.

\section{Introduction}

In general, the thermal regime of the track bed characterizes the course and changes of temperatures in its construction. The course of the thermal regime depends on the structural composition of the track bed, material characteristics (bulk density, moisture, specific heat capacity, thermal conductivity coefficient, ...) and climatic conditions of the area through which the railway track passes. All modifications of the thermal regime of the track bed are aimed at preventing the formation of frost heaves (causing uneven track lifting and disturbance of the track geometry) by limiting some of the necessary conditions for their formation. Adjustment of the thermal regime of the track bed is usually achieved by inserting a protective layer of crushed aggregate, by incorporating thermal insulation layers (TIL) between the frost-susceptible subgrade surface and the railway superstructure or by replacing the frost-susceptible soil (Ižvolt, 2008). The application of TIL can be justified especially in cases when the railway track is built in areas with higher (above $600{ }^{\circ} \mathrm{C}$.day) or high values of the frost indices (above $1000^{\circ} \mathrm{C}$.day). Also, it is suitable when the design of the required construction thickness of the protective layer is not economical. In the conditions of the Railways of the Slovak Republic it is when the thickness of the protective layer is greater than $600 \mathrm{~mm}$.

Observation of changes in soil properties and building materials caused by frost is the subject of research activities in several countries, especially the Nordic countries. Research activities are focused mainly on frost heaves (Long et al., 2018; Wang \& Zhou, 2018; Wang et al., 2014; Zhou et al., 2018), water freezing in porous materials (Kou et al., 2018; Lu et al., 2019; Zhang \& Liu, 2018; Bąk \& Chmielewski, 2019), thermal-technical parameters of soils and building materials (He et al., 2017; Kömle et al., 2007, 2010; Gnip et al., 2001). Significant results of Canadian research (Fredlund, 2019; Pentland, 2000; Soliman et al., 2008; Tam, 2009) led to the development of the Soilvision software (Fredlund, 2011) which addresses various problematic processes occurring in soils. One of these complex processes is the thermal regime of soil, which can be mo-

${ }^{*}$ Corresponding author. E-mail: deividas.navikas@vilniustech.lt 
delled in the software using the SVHeat program product (Thode, 2012).

The paper aims to determine parameters, based on numerical modelling, that significantly affect the freezing of the railway track structure with a built-in thermal insulation layer of extruded polystyrene boards. Thermal insulation materials are characterized by a low value of the thermal conductivity coefficient $\lambda$ compared to common building materials (crushed aggregate, sandy gravel). Their incorporation into the structural composition of the subballast layers will cause significant thermal resistance and prevent the penetration of frost (zero isotherm) to the frost-susceptible subgrade surface. In the past, natural materials (peat, bark, sandy gravel, or crushed aggregate) were used to establish the TIL, but now the emphasis is on saving natural resources of building materials, and therefore the use of alternative artificial or waste materials is preferred. These materials include Keramzit (Liapor) - light ceramic aggregate, foam glass, polymers (polyurethane, extruded polystyrene) and others. Out of these thermal insulation materials, the polymers have the best thermal insulation properties (Göbel, 2007; Göbel \& Lieberenz, 2013).

Polymers and their excellent thermal insulation properties were known as early as the $19^{\text {th }}$ century, but the best-known form of extruded expanded polystyrene (XPS) was only commercialized in the mid- $20^{\text {th }}$ century (Isowall Group, 2018). Thermal insulation materials (especially polymers) are usually applied at the sub-ballast upper surface level (Addison et al., 2016; Nurmikolu \& Kolisoja, 2005; Styrodur, 2019). In the numerical modelling, this method of incorporating the thermal insulation layer is confronted with the method of its incorporation at the subgrade surface level to identify its efficiency in terms of thermal resistance of the structure. The thicker the thermal insulation layer, the higher the thermal resistance of the track bed, and the lower the thermal conductivity coefficient of this layer. In general, however, it is also necessary to take into account the technological possibilities of incorporating the thermal insulation layer into the sub-ballast layers and the investment costs for its establishment in comparison with the conventional building materials.

Input parameters of numerical modelling could be obtained based on the availability of a real model of a railway track on a scale of 1:1 (Experimental stand DRETM). Its structure and material composition are described in Section 1.1.

The following influences are considered among the observed factors of numerical modelling, influencing the freezing of the railway track structure:

- the method of placing the thermal insulation layer in the sub-ballast layers (at the level of the sub-ballast upper surface or the level of the subgrade surface);

- number of tracks (single-track and double-track);

- ballast material fouling;

- air frost index, average annual air temperature;
- amount of snow cover, or $\mathrm{nf}$ factor (which expresses the relationship between the mean daily air temperature and the mean daily temperature on the ballast bed surface).

The result of the numerical modelling is a nomogram for the design of the necessary thickness of the protective layer of crushed aggregate (see Section 2.1), in combination with the design of the necessary thickness of the thermal insulation layer of extruded polystyrene boards. The design of the thermal insulation layer in the structural composition of the sub-ballast layers makes it possible to save resources of natural materials (crushed aggregate), reduce the thickness of the structural composition of the sub-ballast layers and in some cases (high value of air frost index $I_{m}$ ) reduce financial costs of construction. Based on the obtained data on the depth of freezing of the railway track structure, the mathematical expression of the influence of changes of climatic characteristics on the railway track structure freezing is specified in Section 2.2. It specifically focuses on the mutual relation of values used for the railway track dimensioning for the non-traffic load (the air frost index, the average annual air temperature, the thickness of the protective layer and the thermal insulation material - extruded polystyrene).

\section{Materials and applied methods}

This part of the paper will characterize the properties of building materials and compare the freezing of the railway track structure based on the results of experimental and numerical methods for the winter period 2018/2019.

\subsection{Experimental method - Experimental stand}

To conduct the experimental research, six different types of sub-ballast layers, characterized by the different structural and material compositions were built at the campus of the University of Žilina. The structural composition of the sub-ballast layers, besides the commonly used construction materials (gravel), also included the non-standard ones, especially thermal insulation materials (extruded polystyrene - Styrodur, Liapor, Liapor concrete, and foam concrete). Collectively, these six measurement profiles are referred to as Sector A, which is one of the three sectors that make up a real 1:1 railroad model - a part of the Experimental stand DRETM (Figure 1) (Ižvolt et al., 2019). Sector A serve to verification of the material thermotechnical characteristics and monitoring of the thermal regime of the track substructure construction. The other two sectors of this stand (Sectors B and C) serve to verify the deformation resistance of materials incorporated into the sub-ballast layers.

A total of 150 temperature sensors and 20 protective tubes for moisture measurement are built in the individual measurement profiles of the experimental stand of the sector concerned. The reason for their incorporation in the structure is the monitoring of the thermal and moisture regime of the railway track structure and obtaining input parameters for numerical modelling. 


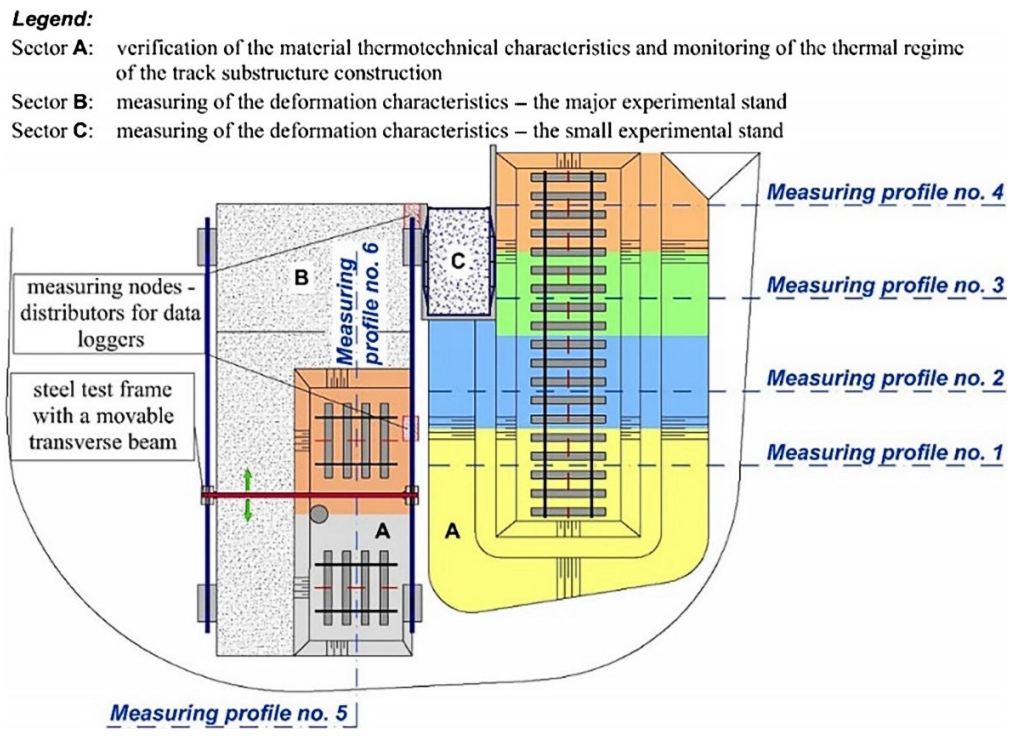

Figure 1. Experimental stand DRETM- ground plan (Pieš \& Môcová, 2019)

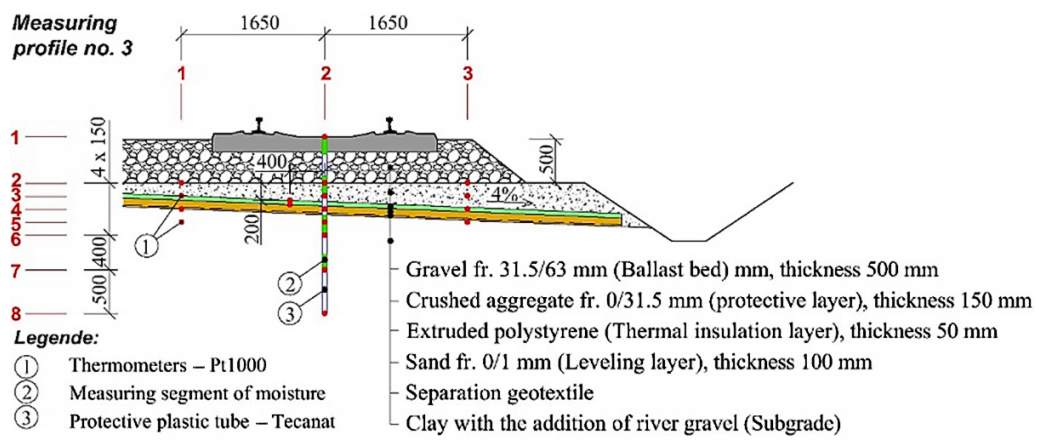

Figure 2. Experimental stand DRETM - measuring profile no. 3 (Pieš, 2020)

As mentioned in the Introduction, the paper examines the effects of the extruded polystyrene (Styrodur) layer incorporated in the experimental stand on the freezing of the railway track structure.

The extruded polystyrene (Styrodur) boards were incorporated in the railway track structure no. 3 (Figure 2). The measuring profile no. 3 consists of a ballast bed, a protective layer of crushed aggregate and extruded polystyrene placed on a levelling layer of sand and a subgrade of clay with river gravel. On the surface of the ballast bed there is a track skeleton consisting of concrete sleepers type SB 8 and rails type 49 E1, which are used for educational purposes (diagnostics of the track skeleton and a comprehensive view of the construction of the railway track). As the track skeleton has a minimal effect on freezing or thermal resistance of the track bed, its influence was not considered within the numerical modelling (following parts of the article).

The temperature of the individual building materials incorporated in the sub-ballast layers can be monitored at 8 depth levels using $18 \mathrm{Pt} 1000$ resistance temperature sensors (see Figure 2 - red circles). The air temperature is measured by a separate protected temperature sensor, located $2.0 \mathrm{~m}$ above the surrounding terrain of the expe- rimental stand. Temperatures are recorded automatically and continuously with the dataTaker DT80 data logger (DataTaker, 2006) at 30-min intervals. The moisture of the individual

building materials in the sub-ballast layers can be monitored along the axis of each measuring profile (in some measuring profiles also at a distance of $1500 \mathrm{~mm}$ from the track centreline) by the built-in protective tube of the Trime Pico IPH T3 hygrometer. It is especially monitored in periods with significant precipitation, or, on the contrary, after a very warm and dry period (IMKO, 2017).

Monitoring of climatic characteristics on the Experimental stand DRETM has been carried out since 2013 (winter period 2013/2014 for measuring profile no. 1). On measuring profile no. 3 (measuring profile with builtin thermal insulation layer of extruded polystyrene in sub-ballast layers) only two winter periods (winer period 2018/2019 and winter period 2019/2020) have been recorded so far since its construction. The most unfavourable winter period in terms of the achieved value of the air frost index and the depth of freezing of the railway track structure (winter period 2018/2019) was used to compare the achieved results of freezing of the railway track structure by experimental and numerical methods. The de- 
termined climatic characteristics of the winter periods in question are demonstrated in Table 1 , where $\theta_{s, \min }$ is the minimum mean daily air temperature of the winter period, $\theta_{s, \max }$ is the maximum mean daily air temperature of the winter period, $\theta_{m}$ is the average annual air temperature, $I_{F}$ is the air frost index, $I_{F S}$ is the frost index on the surface of the ballast bed and $D_{F, \text { max }}$ is the maximum depth of freezing of the structural layers of the railway track during the winter period.

The winter period in which the climatic characteristics were evaluated is the time period bounded by the first and last frost period (in the case of unfavourable winter periods, it can be formed by only one frost period). A sequence of at least three days with a mean daily air temperature $\theta_{s}<-0.1{ }^{\circ} \mathrm{C}$ can be considered as a frost period. The snow cover was removed from the surface of the ballast bed during both winter periods in order to achieve the maximum effects of frost on the railway track structure.

Figure 3 shows the course of freezing of the railway track structure in the winter period 2018/2019 and the maximum value of freezing of the structure achieved.

\subsection{Numerical method - SVHeat}

SoilVision software is the product of SoilVision Systems Ltd., established in the late 20th century. The software was developed primarily based on research conducted on unsaturated soils at the Canadian University of Saskatchewan, as well as at other universities in Canada (SoilVision, 2019).

The first step in numerical modelling was to create a numerical model (Figure 4 - 2D transient model), whose geometrical layout was identical to the geometrical layout of measurement profile no. 3 of the Experimental stand DRETM. The numerical model consists of 5 different material layers (ballast bed of gravel, protective layer of crushed aggregate, thermal insulation layer of extruded polystyrene, leveling layer of sand and subgrade of clay), each of which is defined as a separate region with specific physical and thermal technical properties.

Subsequently, it was necessary to enter the input data of numerical modelling (climatic and material characteristics), obtained by experimental monitoring on the experi-mental stand, or by laboratory measurements (Ižvolt et al., 2013). The input parameters of numerical modelling are demonstrated in Table 2. The temperatures of the individual materials presented in Table 2 characterize the real measured temperatures of the materials (temperature in the middle of the structural layer) built-in the experimental stand determined on January 1, 2018. The moisture content of the individual materials was determined using the time domain reflectometry (TDR) method or the destructive method (sampling and drying) for materials where the use of the TDR method was not possible (ballast bed, extruded polystyrene). The thermal conductivity coefficient and the heat capacity were determined in the laboratory by calorimetry and method of determining the freezing time interval of the structural layer. Within
Table 1. Determined climatic characteristics - measuring profile no. 3 (Pieš, 2020)

\begin{tabular}{|c|c|c|c|c|c|c|}
\hline $\begin{array}{c}\text { Winter } \\
\text { period }\end{array}$ & $\begin{array}{c}\theta_{s, \min }\left({ }^{\circ} \mathrm{C}\right) \\
\theta_{s, \max }\end{array}$ & $\begin{array}{c}\theta_{\mathrm{m}} \\
\left({ }^{\circ} \mathrm{C}\right)\end{array}$ & $\begin{array}{c}I_{F} \\
\left({ }^{\circ} \mathrm{C} . \text { day }\right)\end{array}$ & $\begin{array}{c}I_{F S} \\
\left({ }^{\circ} \mathrm{C} . \text { day }\right)\end{array}$ & $\begin{array}{c}D_{F} \\
(\mathrm{~m})\end{array}$ \\
\hline $2018 / 2019$ & -11.25 & 6.68 & 10.30 & 125 & 125 & 0.653 \\
\hline $2019 / 2020$ & -7.65 & 10.90 & 10.10 & 50 & 49 & 0.490 \\
\hline
\end{tabular}

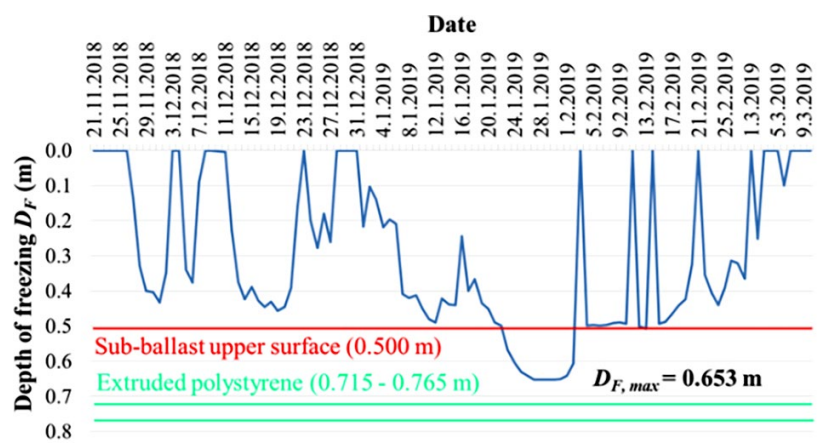

Figure 3. The course of freezing of the railway track structure winter period 2018/2019 (measuring profile no. 3)

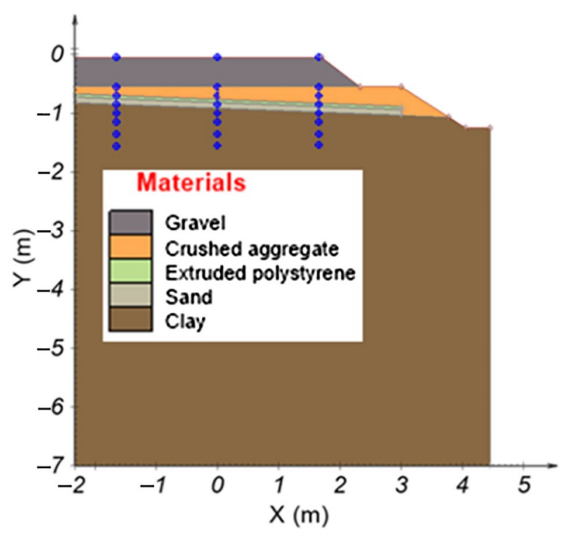

Figure 4. Numerical model - measuring profile no. 3

the numerical modelling, the values of heat capacity and thermal conductivity coefficient of individual materials corresponding to their moisture were used. Knowledge of the relevant input data is essential, as they have a significant effect on the depth of freezing of the railway track structure determined by numerical modelling and also on the relevant comparison of the results.

In the Materials Manager dialog box, in addition to the characteristics demonstrated in Table 2, it was necessary to define the boundary conditions for water freezing (temperature interval of phase change and method for determining the soil freezing characteristic curve) in individual material regions of the model. The soil freezing characteristic curve (SFCC) was set for the subgrade in the software as a function of temperature using an empirical relationship derived by Tice and Anderson (Thode \& Zhang, 2012). The SFCC for sand and gravel was set as a curve derived by Fredlund and Xing (Fredlund, 2011). In other materials (extruded polystyrene and ballast bed), the SFCC was not defined as these materials have a minimum moisture content. The numerical modelling used the cli- 
Table 2. Input parameters of numerical modelling - material characteristics

\begin{tabular}{|l|c|c|c|c|c|}
\hline Structural part/characteristics & Ballast bed (new) & Protective layer & Thermal insulation layer & Levelling layer & Subgrade \\
\hline Layer material & gravel fr. $31.5 / 63 \mathrm{~mm}$ & $\begin{array}{c}\text { crushed aggregate } \\
\text { fr. } 0 / 31.5 \mathrm{~mm}\end{array}$ & extruded polystyrene & sand fr. 0/1 mm & clay \\
\hline Temperature $\left({ }^{\circ} \mathrm{C}\right)$ & 2 & 3 & 5 & 12 & 5 \\
\hline Moisture (\%) & 1 & 5.5 & 35 & 12 & 26 \\
\hline Bulk density $\left({\left.\mathrm{kg} \cdot \mathrm{m}^{-3}\right)}^{\text {Heat capacity }\left(\mathrm{J} \cdot \mathrm{kg}^{-1} \cdot \mathrm{K}^{-1}\right)}\right.$ & 1900 & 1930 & 2060 & 1750 & 1650 \\
\hline $\begin{array}{l}\text { Thermal conductivity } \\
\text { coefficient }\left(\mathrm{W} \cdot \mathrm{m}^{-1} \cdot \mathrm{K}^{-1}\right)\end{array}$ & 980 & 1090 & 0.04 & 960 & 1095 \\
\hline
\end{tabular}

matic characteristics identified for the year 2018 (mean daily air temperatures or average annual air temperature) and winter period 2018/2019 (mean daily air temperatures or air frost index) determined on the measurement profile no. 3 (see Table 1). In the numerical model, the first day of the model (TIME $=1$ ) is January 1,2018 , and the last day of the model $($ TIME $=430)$ is March 6,2019 , the $10^{\text {th }}$ day after the last negative mean daytime temperature in winter $2018 / 2019$. The range of days TIME $=331$ to TIME $=420$ represents the whole winter period 2018/2019 (the effect of the air frost index on the freezing of the railway track structure) and the range of days TIME $=1$ to TIME $=$ 365 represents the year 2018 (the effect of average annual air temperature on the freezing of the railway track structure). Climatic characteristics (representing the climatic load in the numerical model) were defined in a Climate Manager dialog box and assigned as boundary conditions to the individual region edges that are in contact with the air. The analysis and calculation of the freezing of the structural layers of the railway track in the numerical model were realized by the method of finite elements using the program FlexPDE. The solution time step was set to $0.1 /$ day. Visualisation of outputs (see Figure 5 and Figure 6 on the right) of the solution is implemented using the ACUMESH program (Fredlund \& Haihua, 2011). A mesh generation module constructs a triangular $(3,6$, or 9-noded triangles) finite element mesh over an arbitrary

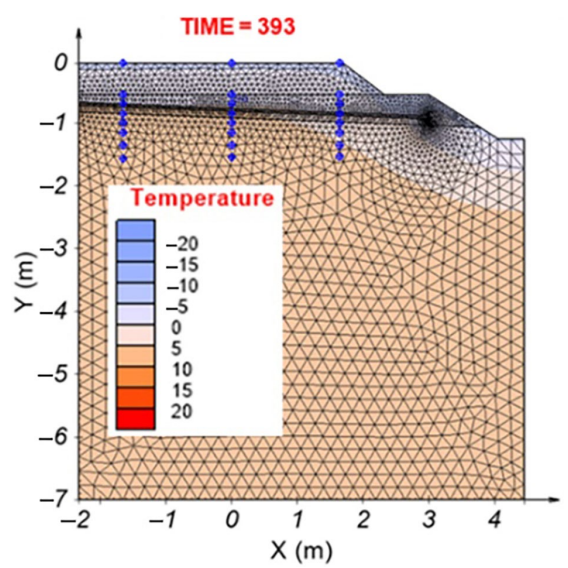

Figure 5. The day of reaching the maximum freezing value of the railway track structure $\left(D_{F}=0.656 \mathrm{~m}\right)$ two-dimensional model domain. The mesh generator allows spatially-varying node density, in order to concentrate cells in regions of structural detail. Figure 5 depicts the $393^{\text {rd }}$ day, which is characterized by the achievement of a maximum freezing depth of the railway track structure in the numerical model $D_{F}=0.656 \mathrm{~m}$.

\subsection{Comparison of achieved results}

By comparing the results of the rail track structure freezing obtained by the experimental and numerical method, it can be stated that if the real input parameters of the numerical modelling obtained in situ or labo are entered, a very good agreement of the monitored parameter can be achieved. The difference between the freezing depth of the railway track structure determined by the experimental method (see Table 1) and the freezing depth determined by the numerical method (see Figure 5) is $0.003 \mathrm{~m}$, which is a negligible or irrelevant difference with regard to the dimensioning methodology of the sub-ballast layers (rounding of the designed construction thickness of the protective layer to $0.05 \mathrm{~m}$ upwards - according to the methodology (Directorate General of Railways of the Slovak Republic, 2005).

In addition to monitoring the position of the zero isotherm or an isotherm characterized by a different temperature, it is possible to monitor the point temperature of the monitored material at different depths in the SVHeat program by defining a network of points of interest (see Figure 4 - blue circles). In the numerical model, the temperature monitoring points of interest are defined in locations identical to the Pt 1000 temperature sensors in the experimental stand (identified for measurement profile no. 3). The differences in temperatures $(\Delta \theta)$ of modelled $\left(\theta_{S V H}\right)$ and actual measured temperatures on particular days of the monitored winter period on the experimental stand $\left(\theta_{22}, \theta_{42}, \theta_{82}\right)$ are demonstrated in Table 3 . The first number in the thermometer marks the row $(2-$ sub-ballast upper surface, 4 - lower edge of the thermal insulation layer, 8 - subgrade) and the second number marks the column ( 2 - rail axis) of the experimental stand structure. In Table 3, the most important date is January 28, 2019 (TIME $=393$ ), when the maximum depth of freezing of the railway track structure was reached. On this day, it can be observed (see Table 3) that the difference between 
the temperature determined by the experimental method and the temperature determined by the numerical method $(\Delta \theta)$ is in all construction levels (at the level of the subballast upper surface, at the level of the lower edge of the thermal insulation layer and at the level of the subgrade) $\pm 0.2{ }^{\circ} \mathrm{C}$. On other days of the winter period $2018 / 2019$, the difference between these temperatures was up to \pm $0.5^{\circ} \mathrm{C}$. From the above, we can state that the differences between experimentally and numerically determined parameters (depth of freezing of the railway track structure and temperature in individual construction levels) are negligible and setting of input parameters of the numerical model is suitable for further use (numerical modelling for design nomogram construction).

\section{Characteristics of the procedure for the construction of the design nomogram}

The protection of the railway track structure against the adverse effects of frost in cases where the subgrade surface is characterized as frost-susceptible is based on the design of a sufficiently thick protective layer of coarse-grained material, currently usually of crushed aggregate. In areas with adverse climatic conditions (high value of the air frost index, or the need for the design of protective layer thickness greater than $0.60 \mathrm{~m}$ ), it is advisable to reduce the protective layer thickness by using suitable thermal insulation material for structural (reduction of the structural thickness of the sub-ballast layers), and also economic reasons.

This part of the paper analyzes the effects of incorporating the thermal insulation material, namely the extruded polystyrene (XPS) boards on the railway track freezing. Moreover, it identifies the factors that most influence the achieved depth of freezing $D_{F}$ of the observed structure. The influence of the method of incorporation of extruded polystyrene in the monitored structure (at the level of the subgrade surface, or the sub-ballast upper surface) was also determined.

Input material characteristics of numerical modelling were determined by laboratory or experimental measurement at the Experimental stand DRETM (Dobeš et al., 2017; Ižvolt et al., 2013; Pieš et al., 2019) and are presented in Table 4. In numerical modelling, in this case (in con-

Table 3. Comparison of temperatures of individual track bed layers determined by experimental and numerical methods

\begin{tabular}{|c|c|c|c|c|c|c|c|c|c|}
\hline Date (TIME in numerical model) & $\begin{array}{c}\theta_{22} \\
\left({ }^{\circ} \mathrm{C}\right)\end{array}$ & $\begin{array}{l}\theta_{S V H} \\
\left({ }^{\circ} \mathrm{C}\right)\end{array}$ & $\begin{array}{c}\Delta \theta \\
\left({ }^{\circ} \mathrm{C}\right)\end{array}$ & $\begin{array}{c}\theta_{42} \\
\left({ }^{\circ} \mathrm{C}\right)\end{array}$ & $\begin{array}{l}\theta_{S V H} \\
\left({ }^{\circ} \mathrm{C}\right)\end{array}$ & $\begin{array}{c}\Delta \theta \\
\left({ }^{\circ} \mathrm{C}\right)\end{array}$ & $\begin{array}{c}\theta_{82} \\
\left({ }^{\circ} \mathrm{C}\right)\end{array}$ & $\begin{array}{l}\theta_{S V H} \\
\left({ }^{\circ} \mathrm{C}\right)\end{array}$ & $\begin{array}{c}\Delta \theta \\
\left({ }^{\circ} \mathrm{C}\right)\end{array}$ \\
\hline $27.10 .2018(300)$ & 10.13 & 9.82 & -0.31 & 14.54 & 14.11 & -0.43 & 15.78 & 15.25 & -0.53 \\
\hline $6.11 .2018(310)$ & 11.89 & 12.06 & +0.17 & 13.74 & 13.25 & -0.49 & 14.47 & 13.99 & -0.48 \\
\hline $16.11 .2018(320)$ & 8.87 & 9.33 & +0.46 & 12.89 & 12.39 & -0.50 & 14.06 & 13.68 & -0.48 \\
\hline $26.11 .2018(330)$ & 6.62 & 6.63 & +0.01 & 11.36 & 11.08 & -0.28 & 13.23 & 13.07 & -0.16 \\
\hline $6.12 .2019(340)$ & 2.78 & 3.11 & +0.33 & 9.37 & 8.98 & -0.39 & 12.09 & 11.86 & -0.23 \\
\hline $16.12 .2018(350)$ & 1.33 & 1.74 & +0.41 & 8.18 & 7.78 & -0.40 & 10.84 & 10.71 & -0.13 \\
\hline $26.12 .2018(360)$ & 1.77 & 2.16 & +0.39 & 7.64 & 7.29 & -0.36 & 9.47 & 9.16 & -0.31 \\
\hline $5.1 .2019(370)$ & 1.54 & 1.58 & +0.04 & 7.02 & 6.63 & -0.39 & 9.02 & 8.63 & -0.39 \\
\hline $15.1 .2019(380)$ & 0.76 & 0.82 & +0.06 & 5.68 & 5.77 & +0.09 & 8.13 & 7.84 & -0.29 \\
\hline $20.1 .2019(385)$ & 0.72 & 0.77 & +0.05 & 5.44 & 5.63 & +0.19 & 7.76 & 7.58 & -0.18 \\
\hline $25.1 .2019(390)$ & -0.38 & -0.62 & -0.24 & 5.10 & 5.19 & +0.09 & 7.50 & 7.33 & -0.17 \\
\hline $28.1 .2019(393)$ & -0.33 & -0.41 & -0.08 & 4.82 & 5.00 & +0.18 & 7.24 & 7.16 & -0.08 \\
\hline 30.1 .2019 (395) & -0.25 & -0.22 & +0.03 & 4.70 & 4.89 & +0.19 & 7.12 & 7.05 & -0.07 \\
\hline $4.2 .2019(400)$ & 0.00 & 0.12 & +0.12 & 4.24 & 4.70 & +0.46 & 6.64 & 6.78 & +0.14 \\
\hline $9.2 .2019(405)$ & 0.10 & 0.43 & +0.33 & 4.18 & 4.65 & +0.47 & 6.44 & 6.56 & +0.12 \\
\hline $14.2 .2019(410)$ & 1.42 & 1.78 & +0.36 & 4.32 & 4.77 & +0.45 & 6.13 & 6.40 & +0.27 \\
\hline
\end{tabular}

Table 4. Input material characteristics of numerical modelling

\begin{tabular}{|c|c|c|c|c|c|}
\hline $\begin{array}{l}\text { Structural part/ } \\
\text { characteristics }\end{array}$ & $\begin{array}{c}\text { Ballast bed } \\
\text { (moderately dirty) }\end{array}$ & Protective layer & Thermal insulation layer & Levelling layer & Subgrade \\
\hline Layer material & $\begin{array}{c}\text { gravel } \\
\text { fr. } 31.5 / 63 \mathrm{~mm}\end{array}$ & $\begin{array}{l}\text { crushed aggregate } \\
\text { fr. } 0 / 31.5 \mathrm{~mm}\end{array}$ & $\begin{array}{l}\text { extruded polystyrene } \\
\text { (Styrodur) }\end{array}$ & sand fr. $0 / 1 \mathrm{~mm}$ & clay \\
\hline Temperature $\left({ }^{\circ} \mathrm{C}\right)$ & -2 & 3 & 3 & 4 & 10 \\
\hline Moisture (\%) & 4 & 5.5 & 12 & 12 & 26 \\
\hline Bulk density $\left(\mathrm{kg} \cdot \mathrm{m}^{-3}\right)$ & 1900 & 1930 & 35 & 1750 & 1650 \\
\hline Heat capacity $\left(\mathrm{J} \cdot \mathrm{kg}^{-1} \cdot \mathrm{K}^{-1}\right)$ & 980 & 1090 & 2060 & 960 & 1095 \\
\hline $\begin{array}{l}\text { Thermal conductivity } \\
\text { coefficient }\left(\mathrm{W} \cdot \mathrm{m}^{-1} \cdot \mathrm{K}^{-1}\right)\end{array}$ & 1.00 & 1.73 & 0.04 & 2.00 & 1.55 \\
\hline
\end{tabular}


trast to the input parameters demonstrated in Table 2), the most unfavourable input material characteristics are used (lower material temperature of the structural layers of the railway track, moderately dirty ballast bed). This process was approached due to numerical modelling of the unfavourable condition (railway track in operation -moderately dirty ballast bed), the effect of less favourable climatic load (less favourable air frost index and average annual air temperature) and different geometrical layout of structural layers of the sub-ballast layers (greater thickness of the protective layer). The soil freezing characteristic curve (SFCC) was defined in the same way as in Section 1.2.

The result of this part of the paper is the identification of the factors that most influence the freezing of the structural layers of the railway track structure. These factors were then used to compile a design nomogram for dimensioning of the sub-ballast layers for non-traffic load (see Section 2.1), where part of the protective layer is replaced by thermal insulation material (extruded polystyrene).

For this purpose, a total of three railway track models (see Figure 6) were created, which were subject to following boundary climatic conditions used in numerical modelling $\left(I_{F}=2000{ }^{\circ} \mathrm{C}\right.$.day, $\theta_{m}=-1{ }^{\circ} \mathrm{C}, I_{F}=1400{ }^{\circ} \mathrm{C}$.day, $\theta_{m}=3{ }^{\circ} \mathrm{C}$ and $I_{F}=600{ }^{\circ} \mathrm{C}$.day, $\theta_{m}=6{ }^{\circ} \mathrm{C}$ ). The average annual air temperature $\theta_{m}$ in the numerical model is represented by the range of days TIME $=1$ to TIME $=$ 365. The frost period in numerical models is defined for the air frost index $I_{F}=600{ }^{\circ} \mathrm{C}$.day and average annual air temperature $\theta_{m}=6^{\circ} \mathrm{C}$ for 110 days (28 November to 17 March - TIME $=333$ to TIME $=442)$ and air frost in$\operatorname{dex} I_{F}=2000^{\circ} \mathrm{C}$.day and average annual air temperature $\theta_{m}=-1{ }^{\circ} \mathrm{C}$ for 255 days ( 3 October to 14 June - TIME $=$ 277 to TIME $=531$ ).

Figure 6 presents numerical models with the different structural and geometrical layout of the sub-ballast layers, where the thickness of the protective and thermal insulation layer was designed to withstand the maximum climatic load $\left(I_{F}=2000{ }^{\circ} \mathrm{C}\right.$.day, $\left.\theta_{m}=-1{ }^{\circ} \mathrm{C}\right)$. Other numerical models with a defined lower climatic load $\left(I_{F}<2000^{\circ} \mathrm{C}\right.$.day, $\theta_{m}>-1{ }^{\circ} \mathrm{C}$ ) differ in the design of a smaller structural thickness of the protective and thermal insulation layer. The achieved maximum depths of freezing of the railway track structure, corresponding to a particular climatic load and a particular structural or geometrical composition of the sub-ballast layers are given in Table 5 , where $I_{F}$ is the air frost index, $\theta_{m}$ is the average annual air temperature, $t_{\text {snow }}$ is the thickness of the snow cover, $\mathrm{nf}$ is a factor expressing the dependance between the mean daily air temperature and the temperature on the surface of the ballast bed, $t_{P L}$ is the thickness of the protective layer, $t_{X P S}$ is the thickness of the thermal insulation layer of extruded polystyrene and $D_{F, \max }$ is the maximum depth of freezing of the railway track structure.

In Table 5, the most important parameter is the maximum depth of freezing of the railway track structure $\left(D_{F, \max }\right)$, which was identified in individual numerical models (presented in Figure 6). The depth in question depends on the input material characteristics (Table 4), the climatic load $\left(I_{F}, \theta_{m}\right.$ and $t_{\text {snow }} / n f$ - Table 5$)$, the construction thickness of the protective layer $\left(t_{P L}\right)$ and the thermal insulation layer $\left(t_{X P S}\right)$. The achieved railway track structure freezing values demonstrated in Table 5 indicate that the incorporation of a thermal insulation layer (extruded polystyrene) at the sub-ballast upper surface is suitable under the influence of a lower intensity climatic load (air frost index $\leq 1200^{\circ} \mathrm{C}$.day). If the intensity of the climatic load is higher, and there is considerable freezing of the railway track structure in the direction from the embankment slopes to the core, in this case, the application of the thermal insulation material at subgrade surface is more suitable (see Model no. 1 and 2 - air frost index $1400{ }^{\circ} \mathrm{C}$.day and $2000^{\circ} \mathrm{C}$.day).

For the above reasons, and to protect the thermal insulation material from degradation by considerable contact stress between it and the ballast grains when placed at the level of the sub-ballast upper surface, Model no. 3 considers the placement of the thermal insulation material (extruded polystyrene) only at the level of the frost susceptible subgrade surface.

The last observed factor in terms of the impact of the track layout and track geometry on its freezing was the comparison of the single track and the double track and thus the influence of a larger volume of material incorporated into the railway track (Models no. 2 and 3). The achieved freezing values of the railway track structure shown in Table 5 indicate that in case of unfavourable climatic conditions (air frost index $I_{F}>1200^{\circ} \mathrm{C}$.day) and double track (larger material volume of the monitored structure), it is possible to design much smaller protective layer thickness (up to approx. $0.25 \mathrm{~m}$ in the track axis). In the case of more favourable climatic conditions (air frost index $I_{F}=600^{\circ} \mathrm{C}$.day), it is necessary to design the same, i.e. minimum protective layer thickness of $0.15 \mathrm{~m}$, in combination with extruded polystyrene $0.03 \mathrm{~m}$ thick boards. In the following procedure of numerical modelling, the most unfavourable case is considered, i.e. the single track (Model no. 2).

In the case of monitoring the influence of changes in physical properties of the ballast bed and consequent changes of its thermal-technical properties on the railway track structure freezing, the ballast bed used for numerical modelling is both clean and moderately dirty ( $4 \%$ content of polluting or fine-grained particles). The Model no 2 . (see Figure 6), in which a material moisture value of $1.0 \%$ and a corresponding value of the thermal conductivity coefficient of $0.70 \mathrm{~W} \cdot \mathrm{m}^{-1} \cdot \mathrm{K}^{-1}$ are used for a clean ballast bed, is used as a reference model. For the moderately dirty ballast bed, the material parameters given in Table 4, which were determined by laboratory measurements or long-term experimental monitoring (material moisture of $4.0 \%$ and the thermal conductivity coefficient of $1.0 \mathrm{~W} \cdot \mathrm{m}^{-1} \cdot \mathrm{K}^{-1}$ ), were considered. The specific heat capacity and bulk density of materials in the numerical model are entered for the dry state, so these parameters remained unchanged. The achieved values of the track structure freezing, depending on the change of monitored parameters, 
are given in Table 6, where $I_{F}$ is the air frost index, $\theta_{m}$ is the average annual air temperature, $t_{\text {snow }}$ is the thickness of the snow cover, $\mathrm{nf}$ is a factor expressing the dependance between the mean daily air temperature and the tempera- ture on the surface of the ballast bed, $t_{P L}$ is the thickness of the protective layer, $t_{X P S}$ is the thickness of the thermal insulation layer of extruded polystyrene and $D_{F, \max }$ is the maximum depth of freezing of the railway track structure.

Model no. 1 - Extruded polystyrene built-in at the level of the sub-ballast upper surface, single track $\left(I_{F}=2000{ }^{\circ} \mathrm{C}\right.$. day, $\left.\theta_{m}=-1{ }^{\circ} \mathrm{C}\right)$
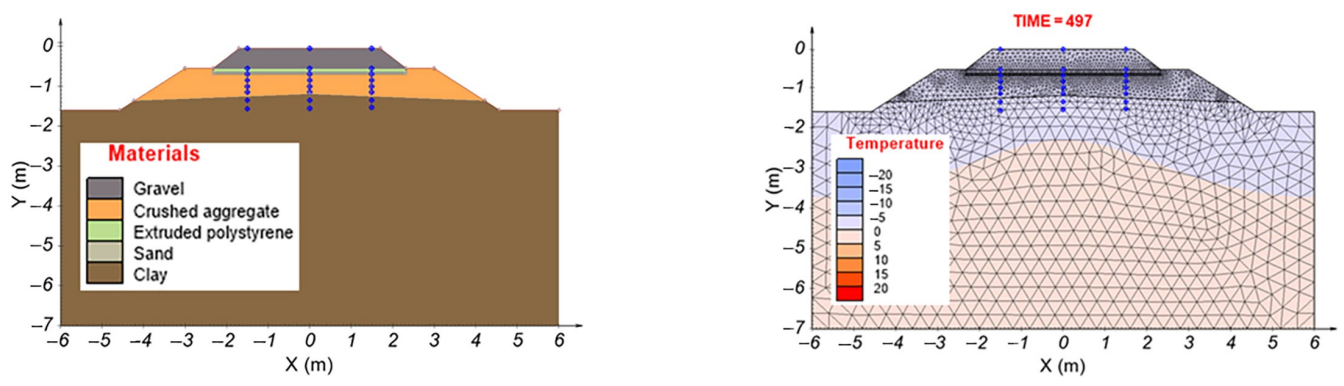

Model no. 2 - Extruded polystyrene built-in at the level of subgrade surface, single track $\left(I_{F}=2000{ }^{\circ} \mathrm{C} . \mathrm{day}, \theta_{m}=-1^{\circ} \mathrm{C}\right)$
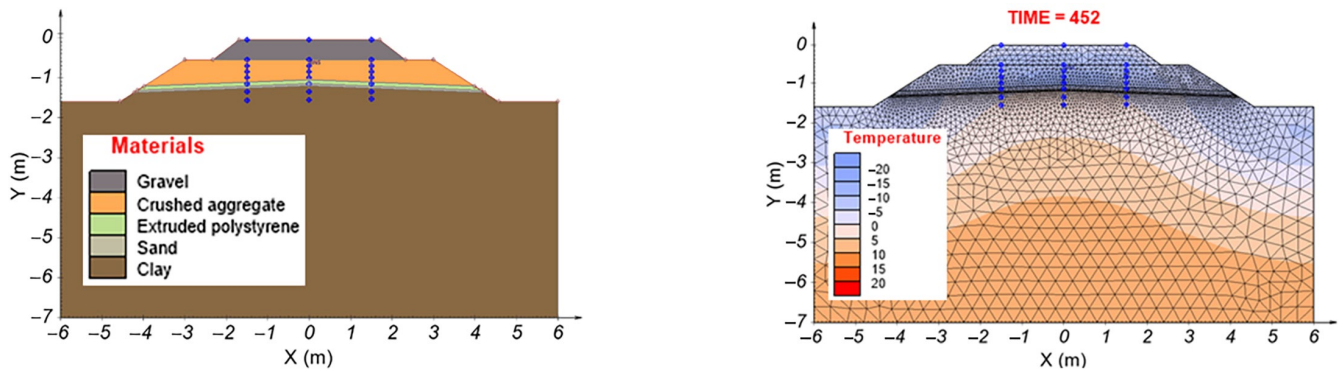

Model no. 3 Extruded polystyrene built-in at the level of subgrade surface, double track $\left(I_{F}=2000{ }^{\circ} \mathrm{C}\right.$. day, $\left.\theta_{m}=-1^{\circ} \mathrm{C}\right)$
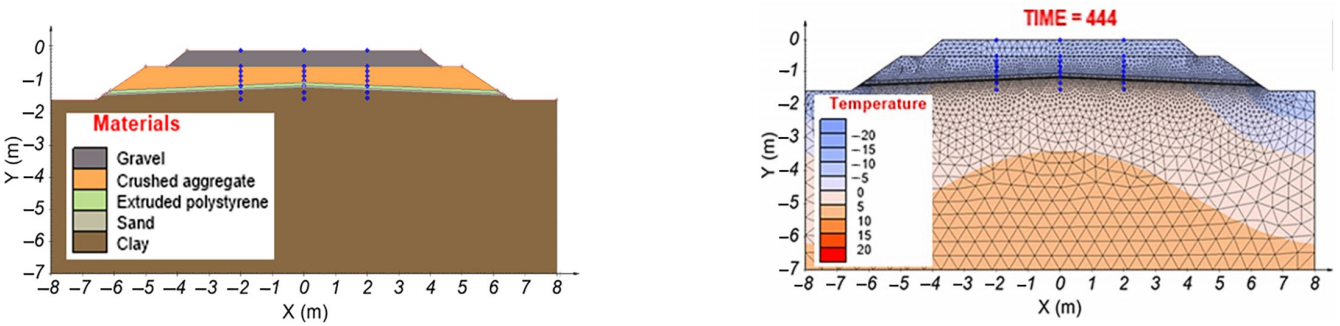

Figure 6. Overview of created models for assessment of various input modelling parameters (images on the left) and the corresponding days of the numerical model with a maximum achieved freezing depths of the railway track structure (images on the right)

Table 5. Achieved depths of freezing of the railway track structure corresponding to the numerical models depending on different climatic loads

\begin{tabular}{|c|c|c|c|c|c|c|c|}
\hline Model no. & $I_{F}\left({ }^{\circ} \mathrm{C}\right.$. day $)$ & $\theta_{m}\left({ }^{\circ} \mathrm{C}\right)$ & $t_{\text {snow } /} n f(\mathrm{~m}) /(-)$ & $t_{P L}(\mathrm{~m})$ & $t_{X P S}(\mathrm{~m})$ & $D_{F, \max }(\mathrm{m})$ & TIME in numerical model \\
\hline 1 & 600 & 6 & $0.18 / 0.65$ & 0.15 & 0.03 & 0.56 & 400 \\
\hline 1 & 1400 & 3 & $0.23 / 0.55$ & 0.15 & 0.10 & 0.65 & 451 \\
\hline 1 & 1400 & 3 & $0.23 / 0.55$ & 0.50 & 0.05 & 1.12 & 472 \\
\hline 1 & 2000 & -1 & $0.23 / 0.55$ & 0.50 & 0.10 & 2.20 & 497 \\
\hline 2 & 600 & 6 & $0.18 / 0.65$ & 0.15 & 0.03 & 0.67 & 400 \\
\hline 2 & 1400 & 3 & $0.23 / 0.55$ & 0.15 & 0.10 & 0.74 & 443 \\
\hline 2 & 1400 & 3 & $0.23 / 0.55$ & 0.50 & 0.05 & 1.075 & 450 \\
\hline 2 & 2000 & -1 & $0.23 / 0.55$ & 0.50 & 0.10 & 1.13 & 452 \\
\hline 3 & 600 & 6 & $0.18 / 0.65$ & $0.50^{*} / 0.58$ & 0.00 & 0.96 & 400 \\
\hline 3 & 1400 & 3 & $0.23 / 0.55$ & $0.15^{*} / 0.23$ & 0.05 & 0.78 & 444 \\
\hline 3 & 2000 & -1 & $0.23 / 0.55$ & $0.15^{*} / 0.23$ & 0.10 & 0.825 & 444 \\
\hline
\end{tabular}

Note: ${ }^{*}$ in the axis of the double-track axes. 
Table 6. Achieved depths of freezing of the railway track structure depending on the moisture of the protective layer and the quality condition of the ballast bed (its fouling)

\begin{tabular}{|l|c|c|c|c|c|c|c|}
\hline \multicolumn{1}{|c|}{ Model no. } & $I_{F}\left({ }^{\circ} \mathrm{C}\right.$.day) & $\theta_{m}\left({ }^{\circ} \mathrm{C}\right)$ & $t_{\text {snow }} n f(\mathrm{~m}) /(-)$ & $t_{P L}(\mathrm{~m})$ & $t_{X P S}(\mathrm{~m})$ & $D_{F, \max }(\mathrm{m})$ & TIME in numerical model \\
\hline 2 (clean BB) & 600 & 6 & $0.18 / 0.65$ & 0.30 & - & 0.77 & 402 \\
\hline 2 (clean BB) & 1400 & 3 & $0.23 / 0.55$ & 0.30 & 0.05 & 0.87 & 450 \\
\hline 2 (clean BB) & 2000 & -1 & $0.23 / 0.55$ & 0.40 & 0.10 & 1.025 & 452 \\
\hline 2 (contamined BB) & 600 & 6 & $0.18 / 0.65$ & 0.15 & 0.03 & 0.67 & 400 \\
\hline 2 (contaminated BB) & 1400 & 3 & $0.23 / 0.55$ & 0.50 & 0.05 & 1.075 & 450 \\
\hline 2 (comtaminated BB) & 2000 & -1 & $0.23 / 0.55$ & 0.50 & 0.10 & 1.13 & 452 \\
\hline
\end{tabular}

By comparing the maximum depths of freezing of the railway track presented in Table 6, it can be concluded that the fouling of the ballast bed has a significant effect on the railway track structure freezing. In the case of a lower intensity climatic load $\left(I_{F}=600^{\circ} \mathrm{C}\right.$.day, $\left.\theta_{m}=6{ }^{\circ} \mathrm{C}\right)$ and a clean ballast bed, a protective layer of thickness lower in $0.30 \mathrm{~m}$ can be designed. As the intensity of the climatic load increases when the frost starts to act on the side of the embankment, the thickness of the protective layer can be reduced by $0.20 \mathrm{~m}$ for areas with an air frost index $I_{F}=$ $1400{ }^{\circ} \mathrm{C}$.day, $\theta_{m}=3{ }^{\circ} \mathrm{C}$ and by $0.10 \mathrm{~m}$ for areas with air frost index $I_{F}=2000^{\circ} \mathrm{C}$.day, $\theta_{m}=-1{ }^{\circ} \mathrm{C}$.

It should be noted, however, that the existence of a clean ballast bed is not realistic, as the ballast bed is being dirty continually as a result of operational loading (by loose material from leaking railcars, the fallout from the air, technological bed cleaning procedures, etc.). Therefore, in further numerical modelling, the input values for the moderately dirty ballast bed are used.

\subsection{Influence of climatic characteristic change on the railway track structure freezing}

To obtain a comprehensive overview of the factors affecting the freezing of the railway track structure, it is mainly necessary to analyse the influence of changes in climatic characteristics, namely the air frost index $I_{F}$ and the average annual air temperature $\theta_{m}$. The Model no. 2 (see Figure 6), in which the thickness of the protective layer and the thermal insulation material (extruded polystyrene) was modified depending on the intensity of the climatic load applied was interpreted as a reference model. For this purpose, the numerical modelling uses the range of air frost indexes $I_{F}=600$ to $2000{ }^{\circ} \mathrm{C}$.day and their respective annual average temperatures $\theta_{m}=-1$ to $6{ }^{\circ} \mathrm{C}$, which were determined from real measured values of mean daily air temperatures from various meteorological stations in the Slovak Republic. The value of the air frost index $I_{F}=600{ }^{\circ} \mathrm{C}$.day takes into account the limit when it is no longer efficient to design a greater thickness of the protective layer from an ecnonomic point of view (design of a combination of protective layer and thermal insulation material). The value of the air frost index $I_{F}=$ $2000{ }^{\circ} \mathrm{C}$.day is the limit value for areas e.g. the Nordic and Far Eastern countries through which the railways run. The input material characteristics were defined as in Table 4.
The SFCC, the method of defining the climatic load, the method of calculating the freezing of structural layers of the railway track structure, the time step of the solution and the method of visualising the solution outputs are the same as in Section 1.2.

The results of numerical modelling enabled to design a nomogram of the dependence of the structural thickness of the protective layer of the frost-susceptible subgrade surface (crushed aggregate layer) combined with the thermal insulation material (extruded polystyrene) and the dependence on the non-traffic or climatic load (air frost index, average annual air temperature) - Figure 7. Due to comprehensive application of the nomogram in dimensioning the sub-ballast layers depending on the non-traffic load, it also includes a dependence of the structural thickness of the protective layer for the sub-ballast layer, established without the thermal insulation layer.

The correct design of the structural thickness of the sub-ballast layers (protective and thermal insulation layer) should prevent the penetration of zero isotherm to the frost susceptible subgrade surface (freezing of the subgrade surface could cause uneven track lifting during the winter period and decrease in deformation resistance in spring with an adverse effect on required track geometry). The required thickness of the protective layer of crushed aggregate $\left(t_{P L}\right)$ and the thermal insulation layer of extruded polystyrene $\left(t_{X P S}\right)$ is determined from the value of the air frost index of the area of interest (the area where the railway track is designed) - horizontal axis and average annual air temperature - oblique (ascending) lines. The horizontal lines characterize the required thickness of the crushed aggregate protective layer $\left(t_{P L}\right)$, and the area between the dashed lines characterizes the required thickness of the extruded polystyrene $\left(z_{i}\right)$.

\subsection{Mathematical expression of the influence of changes in climatic characteristics on the railway track structure freezing}

Due to the possibility of continuous monitoring of the impact of changes in climatic characteristics (air frost index and average annual air temperature) on the railway track structure freezing and based on the results of numerical modelling (design nomogram for the railway track dimensioning for non-traffic load - Figure 7), the mathematical model expressing the relationship between these quantities was created. 


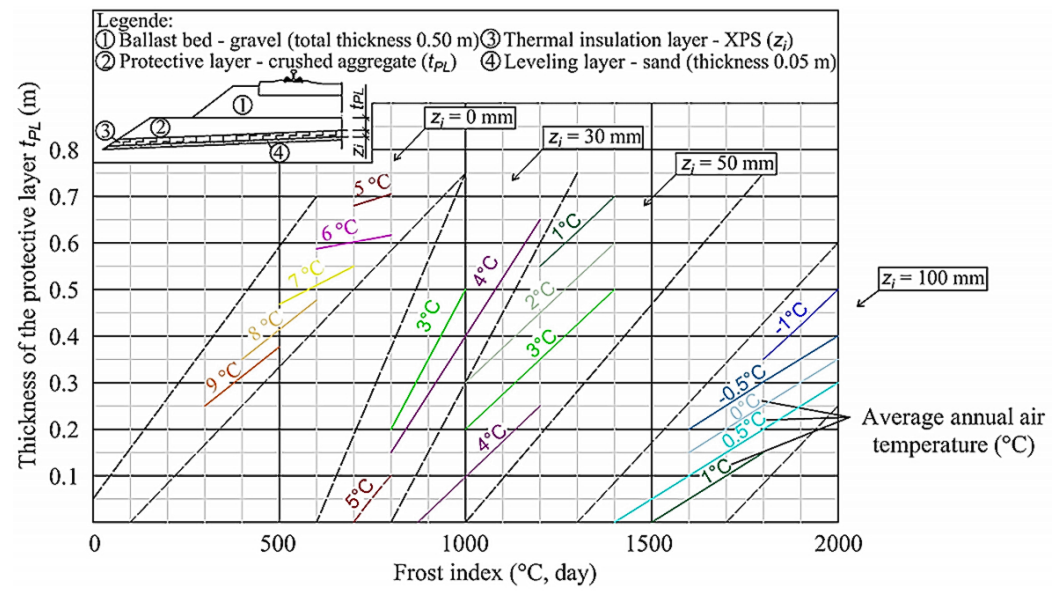

Figure 7. Dependence of the structural thickness of the protective layer of crushed aggregate on the climatic load of the sub-ballast layers with a built-in thermal insulation layer of extruded polystyrene - design nomogram

From the numerically obtained data and their distribution (the average annual air temperature is also negative) and on the basis of the already known relation for calculating the deth of freezing of the railway track structure $D_{F}=0.045 \sqrt{I_{F}}$ (Directorate General of Railways of the Slovak Republic, 2005) can be assumed that there is such an increase in the depth of freezing $D_{F}$ of the railway track structure depending on the air frost index $I_{F}$ and the average annual air temperature $\theta_{m}$, which can be approximated by the power function in the form:

$$
D_{F}=c\left(\theta_{m}+3\right)^{a} I_{F}^{b}, \theta_{m}>-3, I_{F}>0 .
$$

The unknown coefficients are determined by a sufficiently stable method of least squares (Buša et al., 2006) and a sum function is formed:

$$
S(a, b, c)=\sum_{i=1}^{n}\left(c\left(\theta_{m i}+3\right)^{a} I_{F i}^{b}-D_{F i}\right)^{2} .
$$

The minimum of this function determines the coefficients $a, b, c$ in such a way that the sum of the squares of the deviations between the obtained and approximated data will be minimal. To simplify the calculation, the function is logarithmised and the problem is linearised.

The minimum of this function is determined using a system of normal equations:

$$
\begin{aligned}
& 2 \sum_{i=1}^{n}\left(\mathrm{C}+a x_{i}+b y_{i}-f_{i}\right) x_{i}=0, \\
& 2 \sum_{i=1}^{n}\left(\mathrm{C}+a x_{i}+b y_{i}-f_{i}\right) y_{i}=0, \\
& 2 \sum_{i=1}^{n}\left(\mathrm{C}+a x_{i}+b y_{i}-f_{i}\right)=0,
\end{aligned}
$$

where $C=\ln \mathrm{c}, x_{i}=\ln \left(\theta_{m i}+3\right), y_{i}=\ln I_{F i}$, and $f_{i}=\ln D_{F i}$, $i=1, \ldots n$. If marked $Q_{u v}=\left(n \sum_{i=1}^{n} u_{i} v_{i}-\sum_{i=1}^{n} u_{i} \sum_{i=1}^{n} v_{i}\right)$, and $R_{u}=n \sum_{i=1}^{n} u_{i}^{2}-\left(\sum_{i=1}^{n} u_{i}\right)^{2}$, then the unknown coefficients have an expression:

$$
\begin{aligned}
a & =\left(Q_{f y} Q_{x y}-R_{y} Q_{f x}\right) /\left(Q_{x y}^{2}-R_{x} R_{y}\right), \\
b & =\left(Q_{f x} Q_{x y}-R_{x} Q_{f y}\right) /\left(Q_{x y}^{2}-R_{x} R_{y}\right), \\
c & =e^{C}, \\
\text { where } C & =\left(\sum_{i=1}^{n} f_{i}-a \sum_{i=1}^{n} x_{i}-b \sum_{i=1}^{n} y_{i}\right) / n .
\end{aligned}
$$

The global error for this approximation is:

$$
\varepsilon=\sqrt{\sum_{i=1}^{n}\left(c\left(\theta_{m}+3\right)^{a} I_{F i}^{b}-D_{F i}\right)^{2} / n .}
$$

Mathematically obtained values of the depth of freezing of the railway track structure or the thickness of the protective layer are rounded to two decimal places. In case of more favourable climatic conditions $\left(I_{F} \leq 800{ }^{\circ} \mathrm{C}\right.$.day and $\theta_{m} \geq 5^{\circ} \mathrm{C}$ ) and construction of a protective layer only from crushed aggregate (without the use of thermal insulation material in the body of the railway sub-ballast layers), for the calculation of the depth of freezing of the railway track structure or of the thickness of the protective layer the following formulas can be used:

$$
\begin{aligned}
& D_{F}=0.4675\left(\theta_{m}+3\right)^{-0.485} I_{F}^{0.2947} ; \\
& t_{P L}=0.4675\left(\theta_{m}+3\right)^{-0.485} I_{F}^{0.2947}-0.5 .
\end{aligned}
$$

Equations (6) and (7) are valid if the conditions $\theta_{m}>-3, I_{F}>0$ are met. The global error for this particular mathematical model is $\varepsilon \doteq 0.011$. The difference $\Delta D_{F}=$ $D_{F, \text { mat }}-D_{F, \text { num }}$ between the data calculated using this mathematical model (Eqn (6)) and the data obtained by numerical modelling according to the procedure given in Section 2.1 is in the interval $-0.025 ; 0.015$ - see Table 7 . Table 7 also shows the differences between the data determined by the numerical and mathematical method for the construction of the sub-ballast layers with a built-in thermal insulation layer formed by boards of extruded polystyrene thickness $z_{i}=100 \mathrm{~mm}$. The most significant parameter in Table 7 is the difference in the achieved depth 
of freezing of the railway track structure obtained by the mathematical and numerical method $\Delta D_{F}$. It reaches values in the range of $\pm 0.030 \mathrm{~m}$ (for the construction of the sub-ballast layers without extruded polystyrene and with built-in extruded polystyrene of thickness $z_{i}=100 \mathrm{~mm}$ ). Since in the design of the protective layer thickness, its values are rounded (for technological reasons) to the whole $0.05 \mathrm{~m}$ upwards, it is possible to design the same protective layer thickness either applying the numerical method or the mathematical method (Figure 7). The formulas for the calculation of the depth of freezing of the railway track and the required thickness of the protective layer (Eqns (8)-(13)) depending on the specific thickness of the builtin extruded polystyrene $(30 \mathrm{~mm}, 50 \mathrm{~mm}$ and $100 \mathrm{~mm}$ ) in the sub-ballast layers are presented in the following text.

In the case of a reduction of a part of the protective crushed aggregate layer by using extruded polystyrene of thickness $z_{i}=100 \mathrm{~mm}$, for the calculation of the depth of freezing the function (1) is also correct. The functions for the depth of freezing of the railway track structure or the thickness of the protective layer:

$$
\begin{aligned}
& D_{F}=0.00096\left(\theta_{m}+3\right)^{-0.33} I_{F}^{0,958} ; \\
& t_{P L}=0.00096\left(\theta_{m}+3\right)^{-0.33} I_{F}^{0,958}-0.65 .
\end{aligned}
$$

Equations (8) to (9) are valid if the conditions $\theta_{m}>-3, I_{F}>0$ are met. The global error for this particular mathematical model is $\varepsilon \doteq 0.017$. The difference between the data calculated using this mathematical model and the data obtained by numerical modelling is in the interval $-0.030 ; 0.020$.

In the case of high-intensity climatic load $\left(I_{F}>800\right.$ ${ }^{\circ} \mathrm{C}$.day and $\theta_{m}<5{ }^{\circ} \mathrm{C}$ ) and reduction of a part of the protective crushed aggregate layer by using thermal insulation material - extruded polystyrene of thickness $z_{i}=30 \mathrm{~mm}$, we used the function (1) for the calculation of the depth of freezing of the railway track structure or the thickness of the protective layer and we obtain the following formulas:

$$
\begin{aligned}
& D_{F}=0.000219\left(\theta_{m}+3\right)^{-0.59} I_{F}^{1.38} ; \\
& t_{P L}=0.000219\left(\theta_{m}+3\right)^{-0.59} I_{F}^{1.38}-0.58,
\end{aligned}
$$

where is $\theta_{m}>-3, I_{F}>0$. The global error for this particular mathematical model is $\varepsilon \doteq 0.015$. The difference between the data calculated using this mathematical model and the data obtained by numerical modelling is in the interval $-0.030 ; 0.005$.

In the case of a reduction of a part of the protective crushed aggregate layer by using extruded polystyrene of thickness $z_{i}=50 \mathrm{~mm}$, the function (1) applies to the calculation of the depth of freezing, for $\theta_{m}>-3, I_{F}>0$ the functions are:

$$
\begin{aligned}
& D_{F}=0.0029\left(\theta_{m}+3\right)^{-0.6} I_{F}^{0.963} ; \\
& t_{P L}=0.0029\left(\theta_{m}+3\right)^{-0.6} I_{F}^{0.963}-0.6 .
\end{aligned}
$$

The global error for this particular mathematical model is $\varepsilon \doteq 0.023$. The difference between the data calculated using this mathematical model and the data obtained by numerical modelling is in the interval $-0.040 ; 0.045$.

The determined functions for the calculation of the depth of freezing of the railway track structure or of the thickness of the protective layer are considered sufficient, because the calculated thickness is rounded to the whole $50 \mathrm{~mm}$ as part of the dimensioning of the thickness of the protective crushed aggregate layer. Therefore, a global calculation error of about $20 \mathrm{~mm}$ is acceptable (after rounding practically the same values as from numerical modelling are obtained).

Table 7. Comparison of values of the depth of freezing of the railway track structure determined by mathematical $D_{F, \text { mat }}$ and numerical $D_{F, n u m}$ method depending on the air frost index $I_{F}$ and the average annual air temperature $\theta_{m}$ (the sub-ballast layers without and with a built-in thermal insulation layer of extruded polystyrene)

\begin{tabular}{|c|c|c|c|c|c|c|c|c|c|}
\hline \multicolumn{7}{|c|}{ Without thermal insulation layer $z_{i}=0 \mathrm{~mm}$} & \multicolumn{4}{c|}{ With thermal insulation layer $z_{i}=100 \mathrm{~mm}$} \\
\hline $\begin{array}{c}I_{F} \\
\left({ }^{\circ} \mathrm{C} . \text { day }\right)\end{array}$ & $\begin{array}{c}\theta_{m} \\
\left({ }^{\circ} \mathrm{C}\right)\end{array}$ & $\begin{array}{c}D_{F, \text { mat. }} \\
(\mathrm{m})\end{array}$ & $\begin{array}{c}D_{F, \text { num. }} \\
(\mathrm{m})\end{array}$ & $\begin{array}{c}\Delta D_{F} \\
(\mathrm{~m})\end{array}$ & $\begin{array}{c}I_{F} \\
\left({ }^{\circ} \mathrm{C} . \text { day }\right)\end{array}$ & $\begin{array}{c}\theta_{m} \\
\left({ }^{\circ} \mathrm{C}\right)\end{array}$ & $\begin{array}{c}D_{F, \text { mat. }} \\
(\mathrm{m})\end{array}$ & $\begin{array}{c}D_{F, n u m .} \\
(\mathrm{m})\end{array}$ & $\begin{array}{c}\Delta D_{F} \\
(\mathrm{~m})\end{array}$ \\
\hline 800 & 5.0 & 1.220 & 1.205 & 0.015 & 2000 & -1.0 & 1.110 & 1.130 & $-0,020$ \\
\hline 700 & 5.0 & 1.180 & 1.180 & 0.000 & 1800 & -1.0 & 1.000 & 0.995 & 0.005 \\
\hline 800 & 6.0 & 1.150 & 1.140 & 0.010 & 1600 & -1.0 & 0.900 & 0.900 & 0.000 \\
\hline 700 & 6.0 & 1.110 & 1.105 & 0.005 & 2000 & -0.5 & 1.030 & 1.050 & -0.020 \\
\hline 600 & 6.0 & 1.060 & 1.085 & -0.025 & 1800 & -0.5 & 0.930 & 0.940 & -0.010 \\
\hline 700 & 7.0 & 1.050 & 1.050 & 0.000 & 1600 & -0.5 & 0.830 & 0.850 & -0.020 \\
\hline 600 & 7.0 & 1.010 & 1.025 & -0.015 & 2000 & 0.0 & 0.970 & 1.000 & -0.030 \\
\hline 500 & 7.0 & 0.960 & 0.965 & -0.005 & 1800 & 0.0 & 0.880 & 0.890 & -0.010 \\
\hline 600 & 8.0 & 0.960 & 0.970 & -0.010 & 1600 & 0.0 & 0.780 & 0.795 & -0.015 \\
\hline 500 & 8.0 & 0.910 & 0.920 & -0.010 & 2000 & 0.5 & 0.920 & 0.950 & -0.030 \\
\hline 400 & 8.0 & 0.850 & 0.847 & 0.003 & 1800 & 0.5 & 0.830 & 0.835 & -0.005 \\
\hline 500 & 9.0 & 0.870 & 0.865 & 0.005 & 1600 & 0.5 & 0.750 & 0.745 & 0.005 \\
\hline 400 & 9.0 & 0.820 & 0.830 & -0.010 & 1800 & 1.0 & 0.800 & 0.780 & 0.020 \\
\hline 300 & 9.0 & 0.750 & 0.740 & 0.010 & 1600 & 1.0 & 0.710 & 0.725 & -0.015 \\
\hline
\end{tabular}




\section{Results and discussion}

The most important findings from Section 2 are:

1. The use of thermal insulation material (extruded polystyrene) in the sub-ballast layers allows for a considerable reduction of the structural thickness of the protective crushed aggregate layer. This reduction results in the saving of the layer material.

2. In the case of the railway track design for areas with unfavourable climatic conditions (air frost index $I_{F}>$ $1200{ }^{\circ} \mathrm{C}$.day), it is advisable to place the extruded polystyrene thermal insulation layer at the level of the frostsusceptible subgrade surface. The reason is that in the case of its placement at the level of the sub-ballast upper surface, there is significant freezing of the sub-ballast layers also from the sides of the earthwork in the shape of the embankment (see Models no. 1 and 2 in Figure 6 and Table 5). If the extruded polystyrene is placed at the level of the sub-ballast upper surface, this thermal insulation material is also exposed to considerable contact stress (pressing the track ballast grains into the track surface due to the operational load of the track). Due to its protection against degradation, it is advisable to build in at the subgrade surface level also in the areas with more favourable climatic conditions (air frost index $I_{F}<1200^{\circ} \mathrm{C}$.day).

3. In case of a double track located in an area with unfavourable climatic conditions (air frost index $I_{F}>1200$ ${ }^{\circ} \mathrm{C}$.day), it is possible to design a protective layer thickness in the track axis smaller in approx. $0.25 \mathrm{~m}$. In case of designing a double track in more favourable climatic conditions (air frost index $I_{F}=600^{\circ} \mathrm{C}$.day), the number of rails has minimal impact on the railway track structure freezing (the need to design the minimal protective layer thickness of $0.15 \mathrm{~m}$ in combination with the extruded polystyrene boards $0.03 \mathrm{~m}$ thick). A comparison of the influence of a single track or a double track on the railway track structure freezing can be conducted in Figure 6, or in Table 5 (Models no. 2 and 3).

4. The ballast bed moisture (influenced by its fouling) has a fundamental impact on the freezing and position of the zero isotherm in the railway track structure. However, ensuring a long-term clean ballast bed on the railway line is not feasible as it is gradually degraded due to operation. In the case of lower intensity climatic load $\left(I_{F}=600{ }^{\circ} \mathrm{C}\right.$.day, $\left.\theta_{m}=6{ }^{\circ} \mathrm{C}\right)$ and provision of a long-term clean ballast bed, it is possible to design a protective layer of the subgrade surface of the thickness smaller in $0.30 \mathrm{~m}$. As the intensity of the climatic load increases and frost starts to act on the embankment slopes, the thickness of the protective layer can be reduced for areas with an air frost index $I_{F}=1400^{\circ} \mathrm{C}$.day, $\theta_{m}=3{ }^{\circ} \mathrm{C}$ by $0.20 \mathrm{~m}$, and for areas with air frost index $I_{F}=2000^{\circ} \mathrm{C}$.day, $\theta_{m}=-1{ }^{\circ} \mathrm{C}$ by $0.10 \mathrm{~m}$ (see Table 6).

5. Climatic loads (air frost index, average annual air temperature and snow cover thickness) have the greatest impact on the rail track structure freezing, as the extent of change of these parameters is considerable $\left(I_{F}=\right.$
$600{ }^{\circ} \mathrm{C}$.day to $2000{ }^{\circ} \mathrm{C}$.day and $\theta_{m}=-1{ }^{\circ} \mathrm{C}$ to $6{ }^{\circ} \mathrm{C}$ ). Any increase in the frost index value in $200^{\circ} \mathrm{C}$.day (or a decrease in the average annual air temperature by $1{ }^{\circ} \mathrm{C}$ ) results in the need to increase the design of the protective layer thickness by at least $0.15 \mathrm{~m}$ (or $0.10 \mathrm{~m}$ ) and more.

6. The design of the thermal insulation layer of XPS boards in the sub-ballast layers results in considerable material savings of the protective subgrade surface layer of crushed aggregate. Figure 7 indicates that for the air frost index of $I_{F}=800{ }^{\circ} \mathrm{C}$.day and average annual air temperature $\theta_{m}=5{ }^{\circ} \mathrm{C}$ if a $0.03 \mathrm{~m}$ thick thermal insulation layer of XPS board is built-in, it is possible to save more than $0.5 \mathrm{~m}$ of the protective crushed aggregate layer material compared to a structure without a thermal insulation layer. When comparing the designed $0.03 \mathrm{~m}$ thickness of XPS boards with $0.05 \mathrm{~m}$ thickness of XPS boards, built in the sub-ballast layers (or comparing $0.05 \mathrm{~m}$ thickness with $0.10 \mathrm{~m}$ XPS boards thickness), for the design value of the air frost index $I_{F}=$ $1200{ }^{\circ} \mathrm{C}$.day (or $I_{F}=1400^{\circ} \mathrm{C}$.day) and the average annual air temperature $\theta_{m}=4^{\circ} \mathrm{C}$ (or $\theta_{m}=1$ to $3{ }^{\circ} \mathrm{C}$ ), it is possible to achieve material savings of crushed aggregate of approx. $0.40 \mathrm{~m}$ (or $0.35 \mathrm{~m}$ to $0.55 \mathrm{~m}$ depending on the average annual air temperature).

7. The design nomogram (Section 2.1) was created for dimensioning the railway track depending on the nontraffic load, which in the case of high-intensity climatic load $\left(I_{F}>800^{\circ} \mathrm{C}\right.$.day and $\left.\theta_{m}<5^{\circ} \mathrm{C}\right)$ allows the design of the reduced protective layer thickness of crushed aggregate and its replacement with extruded polystyrene of various thicknesses (30 mm, $50 \mathrm{~mm}$ and $100 \mathrm{~mm}$ ). The design nomogram, developed using numerical modelling in SoilVision software (SVHeat programme), was subsequently supplemented by the mathematical model (Section 2.2), which allows continuous monitoring of the depth of freezing of the railway track structure depending on of the sub-ballast layers (with/without thermal insulation layer of extruded polystyrene), the air frost index and the average annual air temperature.

\section{Conclusions and future research}

The aim of achieving the resistance of the railway track structure to the effects of non-traffic load (climatic factors) is to influence particularly the impact of frost and water on the weakest element of the railway track with the conventional railway superstructure (track skeleton placed in the track ballast) - the subgrade surface (in case of finegrained soils). Sufficient protection of the frost-susceptible soils of the subgrade surface can be achieved by incorporating suitable natural non-freezing building materials (e.g. crushed aggregate) or special thermal insulation materials (e.g. extruded polystyrene) with sufficiently high thermal resistance into the structural sub-ballast layers. In addition, their suitable arrangement and sufficient dimensions are important, as has resulted from the long-term experimental work carried out at DRETM since 2003 in 
the field of the impact of non-traffic loads on the dimensioning of protective layers of the sub-ballast layers (see Section 1 and Section 2).

The subject of the future experimental activity will be the assessment of railway track structure with a built-in thermal insulation layer of XPS boards for (static and dynamic) traffic load and the assessment of the suitability of application of other thermal insulation materials (Liapor concrete, foam concrete, foam glass) in terms of traffic and non-traffic load.

\section{References}

Addison, P., Lautala, P., Oommen, T., \& Vallos, Z. (2016). Embankment stabilization techniques for railroads on permafrost. In Proceedings of the 2016 Joint Rail Conference. Columbia, USA. https://doi.org/10.1115/JRC2016-5731

Bąk, A., \& Chmielewski, R. (2019). The influence of fine fractions content in non-cohesive soils on their compactibility and the CBR value. Journal of Civil Engineering and Management, 25(4), 353-361. https://doi.org/10.3846/jcem.2019.9687

Buša, J., Pirč, V., \& Schrötter, Š. (2006). Numerical methods, probability and mathematical statistics Košice (in Slovak). http:// web.tuke.sk/fei-km/sites/default/files/prilohy/1/statnumo.pdf

DataTaker. (2006). DT80 series user's manual. https://asset.conrad.com/media10/add/160267/c1/-/en/000122969ML01/ 000122969ML01.pdf

Directorate General of Railways of the Slovak Republic. (2005). The design of structural layers of subgrade structures (TNŽ 73 6312). Slovak Republic (in Slovak).

Dobeš, P., Ižvolt, L., Mečár, M., \& Malachová, J. (2017). The determination of values of the specific heat capacity of the selected thermal insulation materials used in track bed structure. In Proceedings of the 26th R-S-P Seminar 2017, Theoretical Foundation of Civil Engineering. Warsaw, Poland. https://doi.org/10.1051/matecconf/201711700039

Fredlund, D. G. (2019). State of practice for use of the soil-water characteristic curve (SWCC) in geotechnical engineering. Canadian Geotechnical Journal, 56(8), 1059-1069.

https://doi.org/10.1139/cgj-2018-0434

Fredlund, M. (2011). SOILVISION, A knowledge-based soils database. User's manual. Saskatoon, Saskatchewan, Canada. https://d3pcsg2wjq9izr.cloudfront.net/files/3801/download/86801/17.SoilVision_Users_Manual.pdf

Fredlund, M., \& Haihua, L. (2011). ACUMESH, 2D/3D visualization software. User's manual. Saskatoon, Saskatchewan, Canada.

Gnip, I., Vejjelis, S., \& Keršulis, V. (2001). The equilibrium moisture content of low-density thermal insulating materials. Journal of Civil Engineering and Management, 7(5), 359-365. https://doi.org/10.3846/13921525.2001.10531754

Göbel, C. (2007). Frost protective layer in track substructure (Frostschutzschicht im Eisenbahnunterbau). EI-Eisenbahningenieur, 58(2), 6-12 (in German).

Göbel, C., Lieberenz, K. (2013). Handbook, Earthworks of the Railways: Planning - Dimensioning - Building - Maintenance (Handbuch, Erdbauwerke der Bahnen: Plannung - Bemessung - Ausführung - Instandhaltung). DW Media Group $\mathrm{GmbH}$, Eurailpress (in German).

He, H., Zhao, Y., Dyck, M. F., Si, B., Jin, H., Lv, J., \& Wang, J. (2017). A modified normalized model for predicting effective soil thermal conductivity. Acta Geotechnica, 12(6), 12811300. https://doi.org/10.1007/s11440-017-0563-z
IMKO. (2017). User manual TRIME - PICO T3/IPH44 and T3/ IPH50. https://s3.amazonaws.com/mesasystemscowp/wp-content/uploads/2017/09/Manual_TRIME-PICO-IPH1.pdf

Isowall Group. (2018). A brief history of polystyrene. https://www. isowall.co.za/a-brief-history-of-polystyrene/

Ižvolt, L. (2008). Railway substructure - stress, diagnostics, design and implementation of body construction layers of railway subgrade (Scientific monograph). University of Žilina (in Slovak).

Ižvolt, L., Dobeš, P., \& Hodás, S. (2019). Experimental monitoring and numerical modeling of the thermal regime of selected track substructures. Transport Problems, 14(4), 89-100. https://doi.org/10.20858/tp.2019.14.4.8

Ižvolt, L., Dobeš, P., \& Mečár, M. (2013). Contribution to the methodology of the determination of the thermal conductivity coefficients $\lambda$ of materials applied in the railway subbase structure. Communications, 4, 9-17.

Kou, J., Teng, J., \& Zhang, S. (2018). Experimental study on the unfrozen water content and pore size distribution of frozen soil. Journal of $X i^{\prime}$ An University of Science and Technology, 2, 246-252. https://doi.org/10.13800/j.cnki.xakjdxxb.2018.0211

Kömle, N. I., Bing, H., Feng, W. J., Wawrzaszek, R., Hütter, E. S., He, P., Marczewski, W., Dabrowski, B., Schröer, K., \& Spohn, T. (2007). Thermal conductivity measurements of road construction materials in frozen and unfrozen state. Acta Geotechnica, 2(2), 127-138. https://doi.org/10.1007/s11440-007-0032-1

Kömle, N. I., Hütter, E. S., \& Feng, W. J. (2010). Thermal conductivity measurements of coarse-grained gravel materials using a hollow cylindrical sensor. Acta Geotechnica, 5(4), 211-223. https://doi.org/10.1007/s11440-010-0126-Z

Long, X., Cen, G., Cai, L., \& Chen, Y. (2018). Experimental research on frost heave characteristics of gravel soil and multifactor regression prediction. Advances in Materials Science and Engineering, Article ID 5682619.

https://doi.org/10.1155/2018/5682619

Lu, J., Pei, W., Zhang, X., Bi, J., \& Zhao, T. (2019). Evaluation of calculation models for the unfrozen water content of freezing soils. Journal of Hydrology, 575, 976-985.

https://doi.org/10.1016/j.jhydrol.2019.05.031

Nurmikolu, A., \& Kolisoja, P. (2005). Extruded polystyrene (XPS) foam frost insulation boards in railway structures. In Proceedings of the 16th International Conference on Soil Mechanics and Geotechnical Engineering. Osaka, Japan. https://doi.org/10.3233/978-1-61499-656-9-1761

Pentland, J. S. (2000). Use of a general partial differential equation solver for solution of heat and mass transfer problems in soils [Master thesis]. University of Saskatchewan, Faculty of Civil Engineering, Department of Civil and Geological Engineering. https://harvest.usask.ca/handle/10388/11704

Pieš, J. (2020). Numerical and experimental analysis of the impact of non-traffic load on the construction thickness of the protective layer of the track bed [Doctoral dissertation]. University of Žilina, Faculty of Civil Engineering, Department of Railway Engineering and Track Management.

Pieš, J., Ižvolt, L., \& Dobeš, P. (2019). Experimental Monitoring of Moisture Conditions in the Various Types of Track Bed Structure. In Proceedings of the 5th World Multidisciplinary Earth Sciences Symposium (WMESS 2019). Prague, Czech Republic. https://doi.org/10.1088/1755-1315/362/1/012075

Pieš, J., \& Môcová, L. (2019). Application of TDR test probe for determination of moisture changes of railway substructure materials. In Proceedings of the 13th International Scientific Conference on Sustainable, Modern and Safe Transport (TRANSCOM 2019). Nový Smokovec, Slovak Republic. https://doi.org/10.1016/j.trpro.2019.07.013 
SoilVision. (2019). About. https://soilvision.com/company/about Soliman, H., Kass, S., \& Fleury, N. (2008). A simplified model to predict frost penetration for Manitoba soils. In Proceedings of the Annual Conference of the Transportation Association of Canada. Toronto, Ontario, Canada.

Styrodur. (2019). Load-bearing and floor insulation. https://static1. squarespace.com/static/53f9d90ee4b0572e560769f8/t/54bbe72be4b0567044c061c0/1421600555419/Styrodur+Floor+Application+Brochure.pdf

Tam, A. (2009). Permafrost in Canada's Subarctic Region of Northern Ontario [Master thesis]. University of Toronto.

https://tspace.library.utoronto.ca/bitstream/1807/18954/6/ Tam_Andrew_200911_MSc_thesis.pdf

Thode, R. (2012). SVHEAT, 2D/3D Geothermal modeling software. Tutorial manual. Saskatoon, Saskatchewan, Canada.

Thode, R., \& Zhang, J. (2012). SVHEAT, 1D/2D/3D Geothermal modeling software. Theory manual. Saskatoon, Saskatchewan, Canada.

Wang, P., \& Zhou, G. (2018). Frost-heaving pressure in geotechnical engineering materials during freezing process. International Journal of Mining Science and Technology, 28(2), 287-296. https://doi.org/10.1016/j.ijmst.2017.06.003

Wang, T., Yue, Z., Ma, CH., \& Wu, Z. (2014). An experimental study on the frost heave properties of coarse grained soils. Transportation Geotechnics, 1(3), 137-144. https://doi.org/10.1016/j.trgeo.2014.06.007

Zhang, C., \& Liu, Z. (2018). Freezing of water confined in porous materials: role of adsorption and unfreezable threshold. Acta Geotechnica, 13(5), 1203-1213. https://doi.org/10.1007/s11440-018-0637-6

Zhou, G., Zhou, Y., Hu, K., Wang, Y., \& Shang, X. (2018). Separate-ice frost heave model for one-dimensional soil freezing process. Acta Geotechnica, 13(1), 207-217. https://doi.org/10.1007/s11440-017-0579-4 